Article

\title{
Spatial Accessibility in Urban Regeneration Areas: A Population-Weighted Method Assessing the Social Amenity Provision
}

\author{
Robin Gutting ${ }^{1,2, *}$, Maria Gerhold ${ }^{3}$ and Stefanie Rößler ${ }^{1}$ \\ ${ }^{1}$ Leibniz Institute of Ecological Urban and Regional Development, Germany; E-Mails: r.gutting@ioer.de (R.G.), \\ s.roessler@ioer.de (S.R.) \\ 2 Department of Geography and Environmental Studies, Stellenbosch University, South Africa \\ ${ }^{3}$ Faculty of Spatial Information, University of Applied Sciences Dresden, Germany; \\ E-Mail: maria.gerhold2@htw-dresden.de \\ * Corresponding author
}

Submitted: 28 April 2021 | Accepted: 31 May 2021 | Published: 17 November 2021

\begin{abstract}
Principles of social sustainability serve to guide urban regeneration programmes around the world. Increasingly, the upholding of these principles is subject to qualified evaluation and monitoring. One of the cornerstones of social sustainability is access to basic services. This is also a strategic and operational objective in urban regeneration measures. While indicatorbased evaluations of accessibility do exist, hitherto they have tended to apply descriptive statistics or density parameters only. Therefore, there is a need for small-scale, regularly updated information on accessibility, such as the nearest facility based on street networks and population density. This deficit can often be attributed to the complex methodological requirements. To meet this need, our article presents a method for determining the spatial accessibility of basic services with low data requirements. Accessibility is measured in walking time and linked to the local population distribution. More specifically, GIS tools in connection with land survey data are used to estimate the number of inhabitants per building; the walking time needed to reach four types of social amenity along the street network is then determined for each building; finally, a population-weighted accessibility index is derived and mapped in a 50-m grid. To test this method, we investigated four urban regeneration areas in Dresden, Germany. The results show that with freely available geodata, it is possible to identify neighbourhoods and buildings with both high population densities and poor accessibility to basic services. Corresponding maps can be used to monitor urban regeneration measures or form a basis for further action.
\end{abstract}

\section{Keywords}

accessibility; population mapping; social amenities; socially integrative urban development; spatial network analysis; urban renewal

\section{Issue}

This article is part of the issue "Towards Digital Urban Regeneration: Embedding Digital Technologies Into Urban Renewal Processes and Development" edited by Dalit Shach-Pinsly (Technion-Israel Institute of Technology, Israel).

(C) 2021 by the authors; licensee Cogitatio (Lisbon, Portugal). This article is licensed under a Creative Commons Attribution 4.0 International License (CC BY).

\section{Introduction}

In view of current disparities between prosperous, economically thriving neighbourhoods and those which are socially disadvantaged, urban regeneration "is increasingly seen as being anchored within the sustainable development agenda and should tackle physical, social, economic and environmental issues together"
(Colantonio \& Dixon, 2009, p. 19). The various definitions of social sustainability proposed by scholars of urban regeneration all share the principle of the long-term, fair participation, and use of urban resources by all population groups (Colantonio \& Dixon, 2009). At a more operational level, collaborative urban planning, pleasant urban environments and well-balanced local economies and labour markets are regarded as just as important 
in securing socially sustainable urban regeneration as socio-cultural factors and adequate institutional development (Müller et al., 2019; Nyseth et al., 2019). In practice, these principles are represented by various measures in individual regeneration approaches all across Europe and worldwide aimed at improving large, deprived monofunctional areas built after the Second World War or working-class neighbourhoods erected at the end of the 19th century (Jensen \& Munk, 2007; Wassenberg \& van Dijken, 2011).

In order to evaluate the success of measures intended to foster social sustainability, complex digital technologies and monitoring approaches are increasingly accompanying the regeneration process. A wide variety of qualitative and quantitative methods is employed, supplemented by GIS-approaches to derive spatially differentiated information. Zheng et al. (2014) provide a comprehensive overview of studies on urban regeneration and the evaluation of sustainability. A great deal of research has also been done on providing theoretical frameworks for measuring the level of (social) sustainability of urban regeneration approaches at neighbourhood scale. Key indicators have been proposed, which can be applied before, during and after regeneration projects, given that data requirements are met (Huang et al., 2020; Korkmaz \& Balaban, 2020). Some studies have considered individual aspects of sustainable urban regeneration, focusing on human health or on the perception of streetscapes and the urban fabric, which forms the basis for developing an identity and sense of place within the neighbourhood (del Aguila et al., 2019; Doğan et al., 2020; Ma et al., 2021). In practice, the comprehensive assessment of urban regeneration measures and their success is often demanded by public funding bodies (European Commission, 2021). Depending on the objective of the evaluation, most assessment techniques rely on quantitative or qualitative surveys, document analysis, workshops, case-study analysis, or the calculation of a comprehensive set of indicators (Bundesinstitut für Bau-, Stadt- und Raumforschung \& Federal Ministry for the Environment, Nature Conservation, Building and Nuclear Safety, 2016; European Commission, 2021; Stadt Heidelberg, 2019; Thüringer Ministerium für Infrastruktur und Landwirtschaft, 2020).

The principle of reasonable access to municipal services for all population groups, both spatially and socially, is one of the cornerstones of social sustainability (Müller et al., 2019). It can also be found as a strategic and operational objective in urban regeneration approaches and corresponding legislation (e.g., German Building Code, Chapter 2, 2017; UK Housing and Regeneration Act, Chapter 1, 2008; The Planning Act in Denmark, Part 2, 2007). Accessibility is usually understood as the potential for spatial opportunities that can be reached with the help of a transport system (Büttner et al., 2018). Geurs and van Wee (2004) theoretically describe four components of accessibility: (1) land-use component; (2) transportation component; (3) temporal component; and (4) the individual component. The land-use component reflects the land-use system comprising the amount and quality of spatial opportunities (e.g., job or health and social facilities, etc.) as well as the demand for these opportunities at origin locations. Transportation entails the transport system and the effort, which is necessary to reach facilities along the transportation network (e.g. time, money, etc.). The temporal component describes temporal constraints like the time available for participating in certain activities (e.g., work, recreation) and the individual component reflects the specific features of the demanding population, e.g., their needs, abilities, and opportunities depending on people's income, age, and physical condition. Especially those socio-demographic aspects play an important role: Despite good spatial connections, economic- or health-related hurdles may still prevent people from taking advantage of spatial opportunities (Gargiulo et al., 2018; Gharebaghi et al., 2018). Location-based measures are frequently used in accessibility analysis and, among others, evaluate accessibility through the modelling of origin-destination (demand and supply) pairs and the effort to cover the distance between them at different spatial scales ("distance measures"). The shortest way to different facilities by foot, bicycle, public transport, or car is assessed based on different costs, e.g., minutes, money, or volume of $\mathrm{CO}_{2}$ emission (Arellana et al., 2021; Bundesinstitut für Bau-, Stadt- und Raumforschung, 2021; Handy \& Clifton, 2001; Hull et al., 2012; Klaus et al., 2020; Metropolregion Hamburg, 2021; Rossetti et al., 2020). When investigating the supply side, isochrone maps can be constructed, e.g., to depict the accessibility of the surrounding neighbourhood to urban green spaces within a certain timeframe (Kolcsár \& Szilassi, 2017). Infrastructure-based measures focus on the transport system itself, which is often modelled as multi modal street grid covering public transport, private car, or pedestrian accessibility (Geurs \& van Wee, 2004). Structural parameters are calculated, e.g., by applying indexes, graph-based connectivity measures, or space syntax (Hull et al., 2012; Ignaccolo et al., 2020; Smith, 2018).

But research shows that the understanding and use of those concepts and approaches is often limited in practice and fails due to more complex methodological requirements (Boisjoly \& El-Geneidy, 2017; Silva et al., 2019). Some studies that have assessed spatial accessibility in the context of (socially) sustainable urban regeneration measures have adopted fairly simple analytical approaches, i.e., involving surveys and descriptive statistics or datasets such as the number of facilities within a certain buffer area (Shirazi et al., 2020; Zheng et al., 2017). In practice, evaluations have tended to deal only with parameters of spatial density such as square metres of green space per inhabitant or the number of doctors within a municipality (Stadt Dresden, 2017; Stadt Heidelberg, 2019).

Against this background, our aim is to show how the spatial accessibility of social amenities in urban 
regeneration areas in terms of pedestrian accessibility can be precisely assessed using a comprehensive approach that is also easy to apply. In our method, population mapping and spatial network analyses are conducted on the basis of building footprint and road network geodata as well as local data from statistical offices and surveys in order to identify population concentrations where there is an urgent need for more accessible social amenities. Specifically, we analyse the spatial accessibility of four types of basic service by applying a 50-m grid under consideration of the following main influencing factors: (1) the urban street grid; (2) population density; and (3) distribution of social amenities. The focus of the analysis is to create a populationweighted accessibility index based on minimal data inputs, which is a composite of population density and accessibility in minutes (for another example of composite accessibility measures see Pilot et al., 2006).

Following, in Section 2, the case study neighbourhoods and the regeneration framework, the indicators used, and the assessment techniques are described. In Section 3, the results are presented in relation to the four case study neighbourhoods. These results are discussed in Section 4, according to the applied methods. The article finishes with concluding remarks in Section 5.

\section{Material and Methods}

\subsection{Case Study Neighbourhoods}

Our research focuses on four neighbourhoods representing regeneration areas within the city of Dresden (DD), Germany: DD-Pieschen, DD-Neustadt, DD-Friedrichstadt, and DD-Löbtau. As the capital of the state of Saxony, Dresden currently has a population of around 560,000 (see Figures 3 to 7 for the city's location within Germany and Europe). These four historical neighbourhoods with mixed functions were established at the end of 19th century during a period of massive industrialisation and urban growth. Due to poor maintenance of the building stock during the communist era, the buildings and flats in these neighbourhoods were somewhat dilapidated at the time of Germany's reunification in 1990. For DD-Löbtau, for example, around $15 \%$ of the buildings were ruinous and showed severe damage leading to a vacancy rate of more than $30 \%$ in 1990 . With no playgrounds at hand and brownfields used for wild parking and illegal waste dumping, attractive public space was limited (Stadt Dresden, 2021a). In addition, the socio-economic make-up of DD-Friedrichstadt was difficult. Characterised by mostly low-income and socially disadvantaged households, the population showed (and still shows) an above-average proportion of recipients of state transfer payments, which corresponds to a population share of $18.5 \%$ compared to the citywide average of $11.2 \%$ in 2014 (Stadt Dresden, 2021b). However, public regeneration policies and programmes over the last three decades have resulted in widespread urban renewal: Since the 1970s, municipalities (initially in West Germany) have received finance from the national urban development support programme Städtebauförderung ("German National Framework of Urban Development Assistance Programmes for Sustainable Urban Development Structures"), which aims to strengthen cities and towns both economically and socially by removing obstacles to their development. Municipalities can apply for funding to address various urban development problems such as: (1) the loss of functions in inner cities and town centres; (2) housing vacancies and derelict sites; and (3) social deprivation and environmental challenges (Bundesministerium des Innern, für Bau und Heimat, 2020; Rößler et al., 2020). One of the first components in this programme were the so-called "urban renewal and development measures," which for over 20 years have also been implemented at our four case study neighbourhoods. These primarily address weakness in the physical fabric (refurbishment of the housing stock) as well as functionality (maintenance and new establishment of functions).

\subsection{Indicators for Spatial Accessibility of Social Amenities}

As discussed above, a central objective of regeneration activities is to improve access to social amenities by foot. At the same time, spatial accessibility is also an appropriate indicator to measure the progress and success of such activities. Acknowledging the main categories of social amenities as facilities for daily need, health care, recreation, and education, we chose the following amenities as suitable for developing and testing the assessment techniques (Marshall, 2005; Sheffield Hallam University, 2005; Stadt Dresden, 2017): (1) facilities for daily need (e.g., supermarkets); (2) general practitioners' surgeries; (3) green spaces; and (4) nursery schools. The practical relevance of these amenities for our study is confirmed by the direct and indirect renewal activities in the regeneration areas to improve accessibility of these four types of facility in the last 20 years, e.g., by establishing new parks or funding the refurbishment of retail outlets and medical practices in core areas of the neighbourhoods. Moreover, we can safely assume that these amenities are relevant to most regeneration areas and that the necessary input datasets used in the following assessment techniques are widely available.

\subsection{Assessment Techniques}

\subsubsection{Population Mapping}

Our population maps were created using the technique of spatial disaggregation, an established approach for small-scale population mapping, here implemented in an automated five-step workflow (Figure 1; Biljecki et al., 2016; Hecht et al., 2019). 


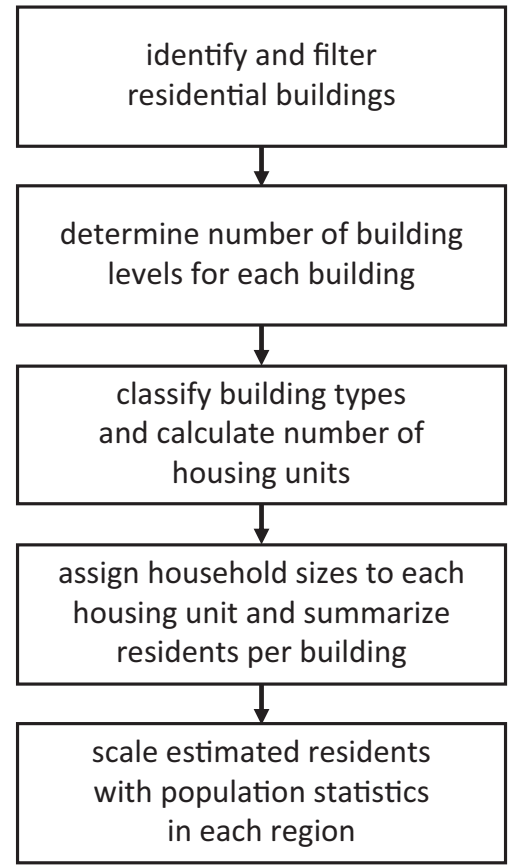

Figure 1. Workflow to estimate the number of people in residential buildings.

Firstly, building footprints from the German land survey register (Authoritative Real Estate Cadastre Information System, 2020) were used to identify and filter residential buildings. This dataset, which is supplied as open data by the Saxon State Office for Geoinformation and Surveying (GeoSN), includes an attribute describing the function of each building, e.g., residential, or industrial use. In addition, geo-referenced point data from GeoSN comprising building addresses were applied to exclude all buildings without an address, since all residential buildings are assigned a house number and street name (GeoSN, 2020b). This ensured, for example, that small auxiliary non-residential buildings were filtered out. Plausibility checks were conducted using residential building data from OpenStreetMap (https:// www.openstreetmap.org). Secondly, most of the information on building levels could be derived from an existing attribute in the 3D city model provided by GeoSN. Verification and plausibility checks were realised by calculating building heights from the digital terrain and surface models from GeoSN and by estimating the number of building levels from this height data and an average figure for storey height (GeoSN, 2020a).

Thirdly, the buildings were classified as single-family houses or apartment buildings with the help of German census data from 2011, which is based on a 100-m grid (Zensus 2011, 2020). Each grid cell specifies the number of buildings contained within it classified by type. The classification was straightforward in the case of cells featuring only one building type by assigning the building type information to the building points falling within the boundary of the respective grid cell. For grid cells with mixed building types, information from OpenStreetMap data was used for classification. Buildings, which could not be classified due to missing information in OpenStreetMap, were compared with already classified edifices in the surrounding area to assign a building type based on similar properties, such as size and structure levels. We assumed one housing unit per building for single family houses and two housing units per level for apartment buildings (Meinel et al., 2009). Plausibility was checked by dividing the number of apartment units in one grid cell indicated by the census data by the summed number of estimated levels in the same grid cell to obtain an average number of housing units per level. While our assumption of two units per level for apartment buildings proved to be reasonable for most buildings, we also found levels with more than two housing units. We used this refined data for further calculations. The total number of housing units per apartment building was determined by multiplying the number of levels with the number of housing units per level.

In a fourth step, household sizes were assigned to each housing unit using another $100-\mathrm{m}$ grid-based census dataset which specifies the relative shares (\%) of different classes of household size (Zensus 2011, 2020). Using these statistics, each housing unit was randomly assigned a household size of one to six people according to the percentages of each class within each $100-\mathrm{m}$ grid cell. The estimated number of members of every household per building was summed to give an estimated total number of residents per building. Finally, the numbers of residents in a building were scaled, based on the real population statistics from 2018 for each city district of Dresden (Meinel et al., 2009). The final results represent a dataset of building polygons with an estimated population attribute for each residential building. The automated workflow was implemented in FME Workbench.

\subsubsection{Accessibility}

The building polygons were converted to point data to clearly select buildings within the boundary of the individual regeneration area (Figure 2). By applying the "1.5 interquartile rule method," buildings with unusually high numbers of residents were excluded as outliers (Khan Academy, 2021). In addition, a 50-m grid was generated for the same spatial extent featuring only those cells which contained at least one residential building point. A resolution of $50 \mathrm{~m}$ is a compromise between the highest possible (small-scale) information and methodological feasibility. At higher resolutions of less than $50 \mathrm{~m}$, grid cells often only contain parts of a single building. Coarser resolutions no longer permit small-scale statements regarding pedestrian accessibility.

To delineate the street and footpath network of Dresden, we opted for open data from the German land survey register for the year 2019 (GeoSN, 2020c) instead of using Open Street Map data. Data from the German land survey register are regularly modeled across Germany according to uniform criteria and are 


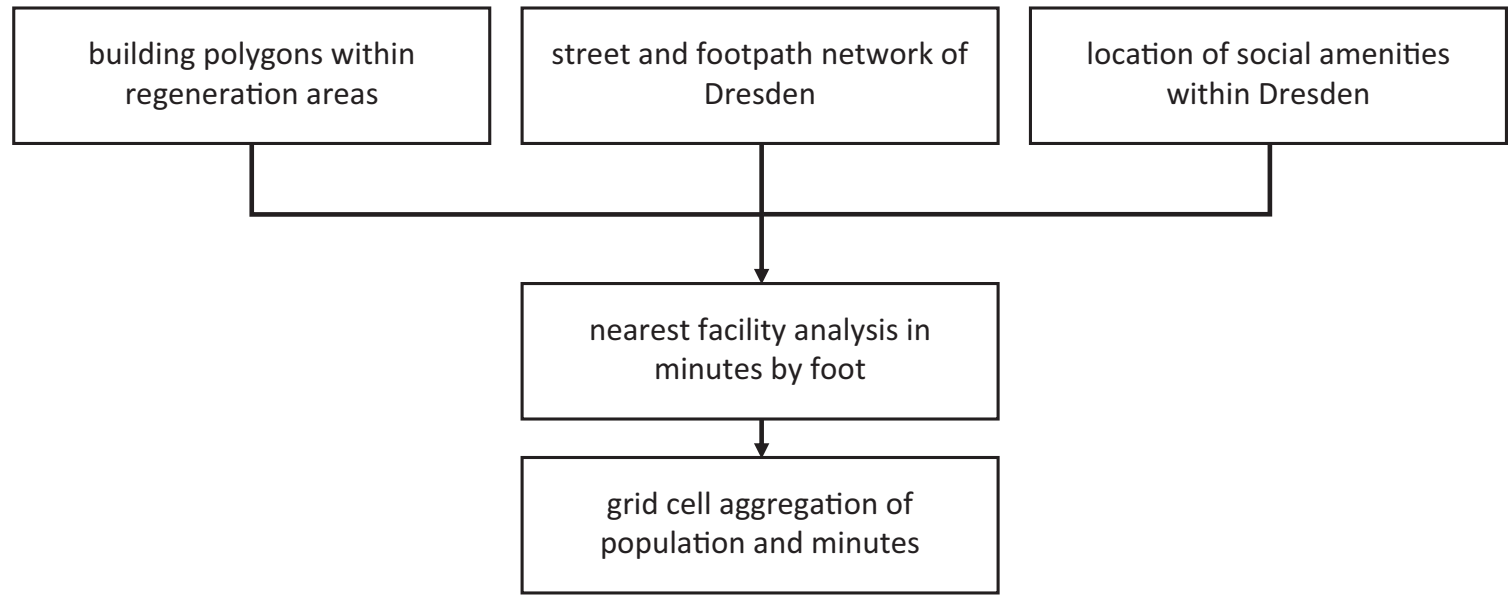

Figure 2. Workflow to estimate the accessibility of social amenities.

therefore available area-wide and in greater topicality as well as completeness. Motorways were deleted from the dataset as they cannot be used by foot. The resulting geometries of streets and footpath were merged and checked for any topology errors. Geodata in the form of point data referring to the above-mentioned four social amenities was taken from the open data portal of the city of Dresden for the year 2020 (Stadt Dresden, 2020). To capture facilities for daily need, we identified grocery stores of all sizes. Access to health care was analysed by identifying the surgeries of general practitioners while ignoring specialists (e.g., paediatricians), dental surgeries, and hospitals. To capture green spaces, we identified public parks and urban forests with a minimum size of one hectare as this was considered sufficient for most recreational activities (e.g., ball games) and the construction of basic facilities. In terms of nursery schools, we opted for private and public facilities.

Using the small-scale population distribution, the street/footpath network, and the location of the social amenities, it was possible to apply the ArcGIS Extension Network Analyst to determine the nearest facilities inside and outside the regeneration areas at a walking speed of $5 \mathrm{~km} / \mathrm{hr}$, which represents the average walking speed of an adult without physical disabilities (Mohler et al., 2007). As a result, four new attributes were obtained for each building within the investigated area indicating the shortest distance in minutes to the nearest social amenity.

To aggregate the population estimations and derive the average walking distance in minutes within the $50-\mathrm{m}$ grid cells it was necessary to multiply the number of people in each building point by the calculated distance to the nearest facility. Then a spatial join was made between the buildings and the grid cells. The resulting building point data obtained the grid cell tile ID, which made it possible to apply a summary statistics operation for the population and the multiplied overall minutes of the four accessibility attributes according to the tile ID. Finally, a division of the summed-up minutes by the total number of people led to an average accessibility per per- son in minutes in every grid cell. The five aggregated attributes can be found in Figures 3 to 6 in the layers "Population per grid cell" and "Accessibility per person in minutes."

\subsubsection{Population-Weighted Accessibility}

To take account of population density in the assessment of accessibility, these two parameters were combined in one dimensionless index. For this purpose, the parameters were normalized to a value of between zero and one. The basis of the normalisation was the value range of the population density of the grid cells within the four regeneration areas as well as the value range for walking times to each of the four social amenities. For example, grid cells with the highest population per grid cell (194 people) were assigned the value one and grid cells with the lowest number of people the value zero. In the case of the social amenity "General practitioner" (Figure 4), the longest walking time in the regeneration areas was around 13 min per person, which was assigned a grid cell value of one; grid cells with an accessibility of less than one minute per person were given the value zero. Then we weighted the normalized accessibility with the corresponding normalised population density in each grid cell by multiplying these values. For easier representation in the maps, the index was then converted into the value range 0 to 10 . Grid cells with index values of 5 to 10 indicate areas and buildings which have comparatively poor accessibility due to longer walking distances and higher population densities, i.e., a greater number of people are affected by the poor accessibility (Figure 7).

\section{Results}

By applying the method presented above, we were able to create two thematic layers in a raster map. The population density layer depicts the number of estimated people in a 50-m grid cell, i.e., number of people per $2,500 \mathrm{~m}^{2}$, and is shown in all figures (Figures 3 to 7). The second layer indicates the accessibility of the four 

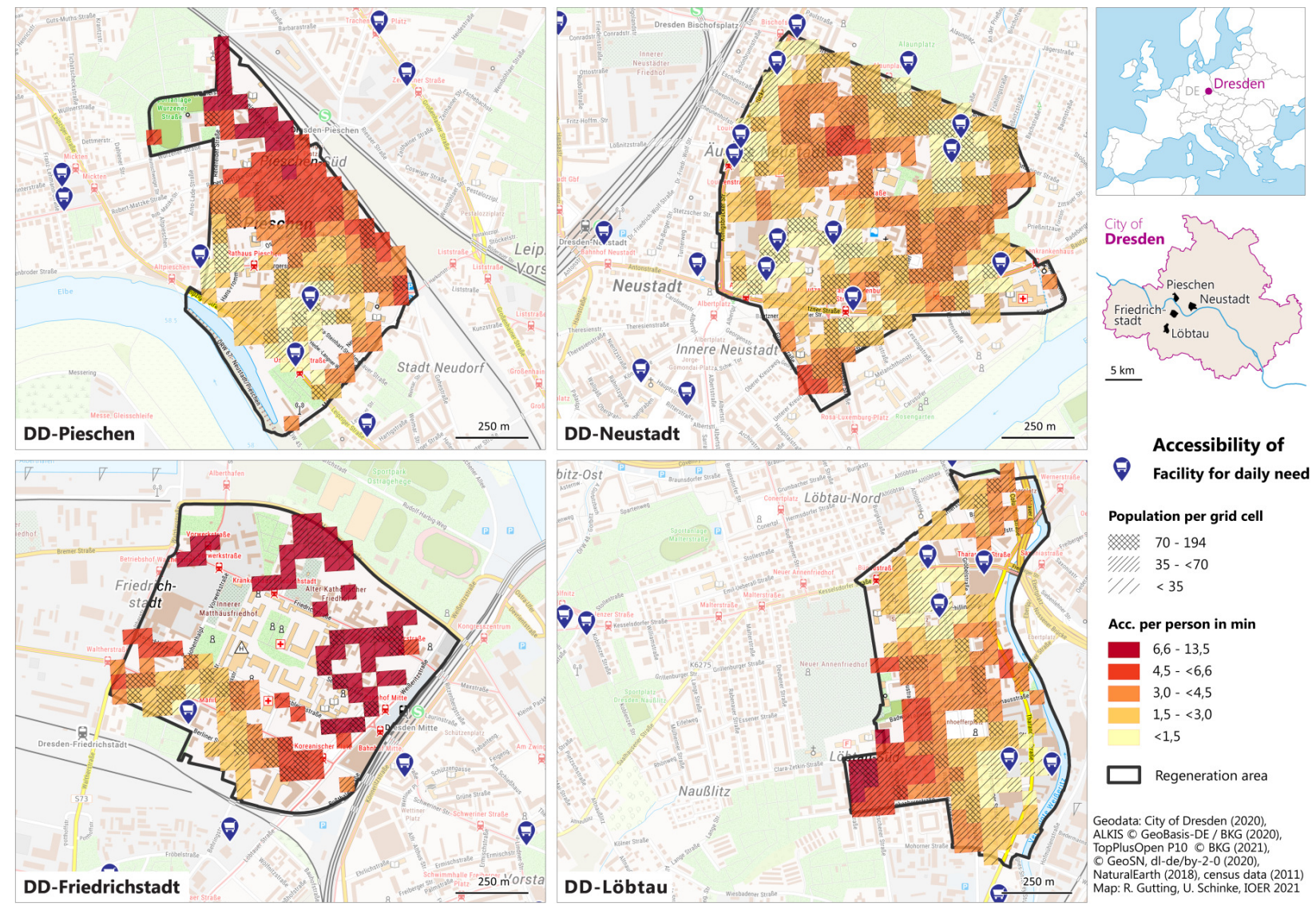

Population per grid cell

$70-194$ $35-<70$ $<35$

Acc. per person in min

$6,6-13,5$

$4,5-<6,6$

$3,0-<4,5$
$1,5-<3,0$ $<1,5$

$\square$ Regeneration area

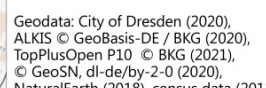

DD-Löbtau

Map: R. Gutting, U. Schinke, IOER

Figure 3. Grid cells showing population density and walking distance in minutes to nearest facility for daily need.
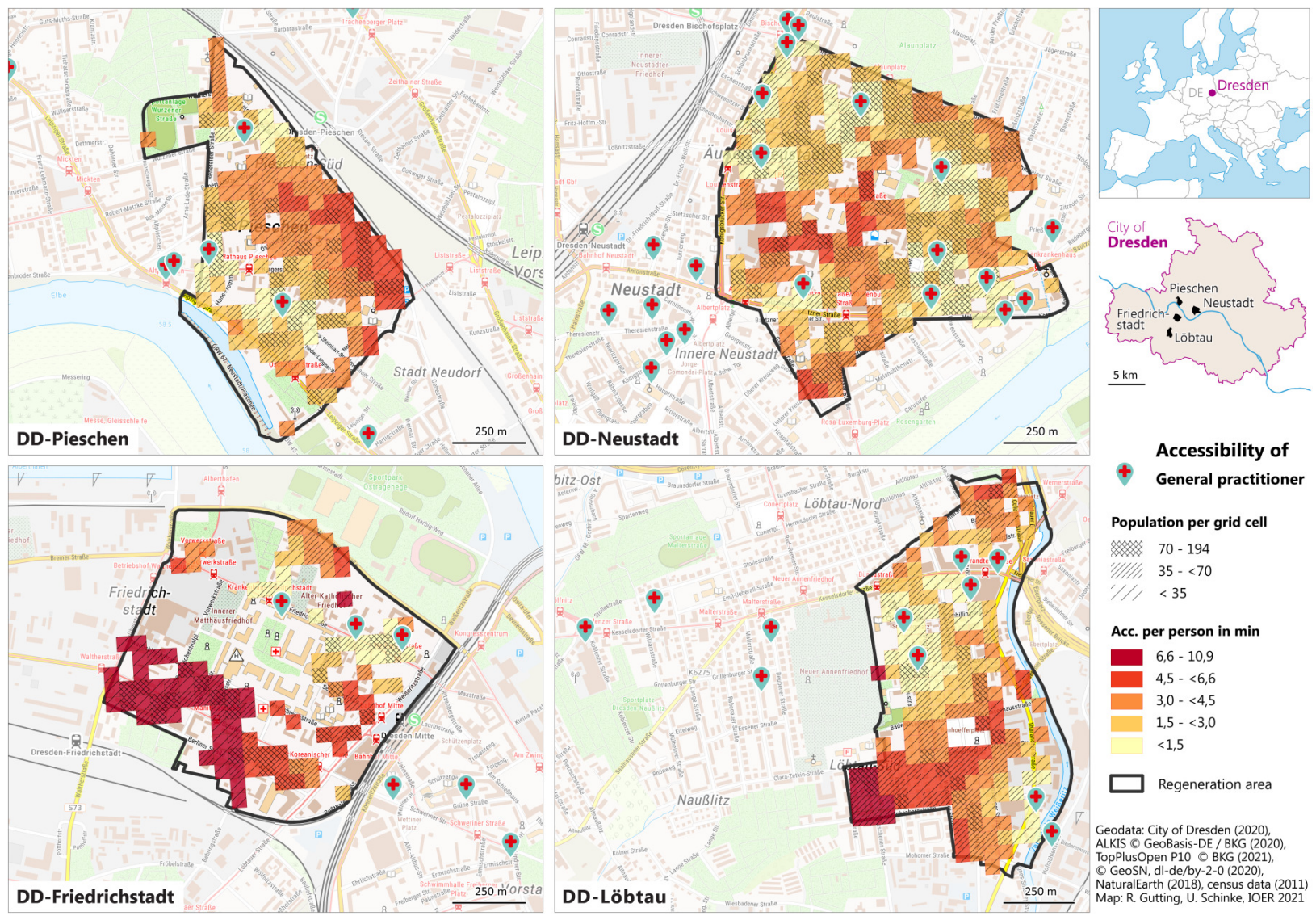

Population per grid cell

$70-194$ $35-<70$ $<35$

Acc. per person in $\mathrm{min}$

$6,6-10,9$
$4,5-<6$

$3,0-<4,5$

$1,5-<3,0$

$<1,5$

$\square$ Regeneration area

Geodata: City of Dresden (2020),
ALKIS O GeoBasis-DE / BKG (2020),
TopPlusOpen P10 O OBG (2021),
Op GeoSN, dl-de/by-2-O (2020),
Nater

Figure 4. Grid cells showing population density and walking distance in minutes to nearest general practitioner. 

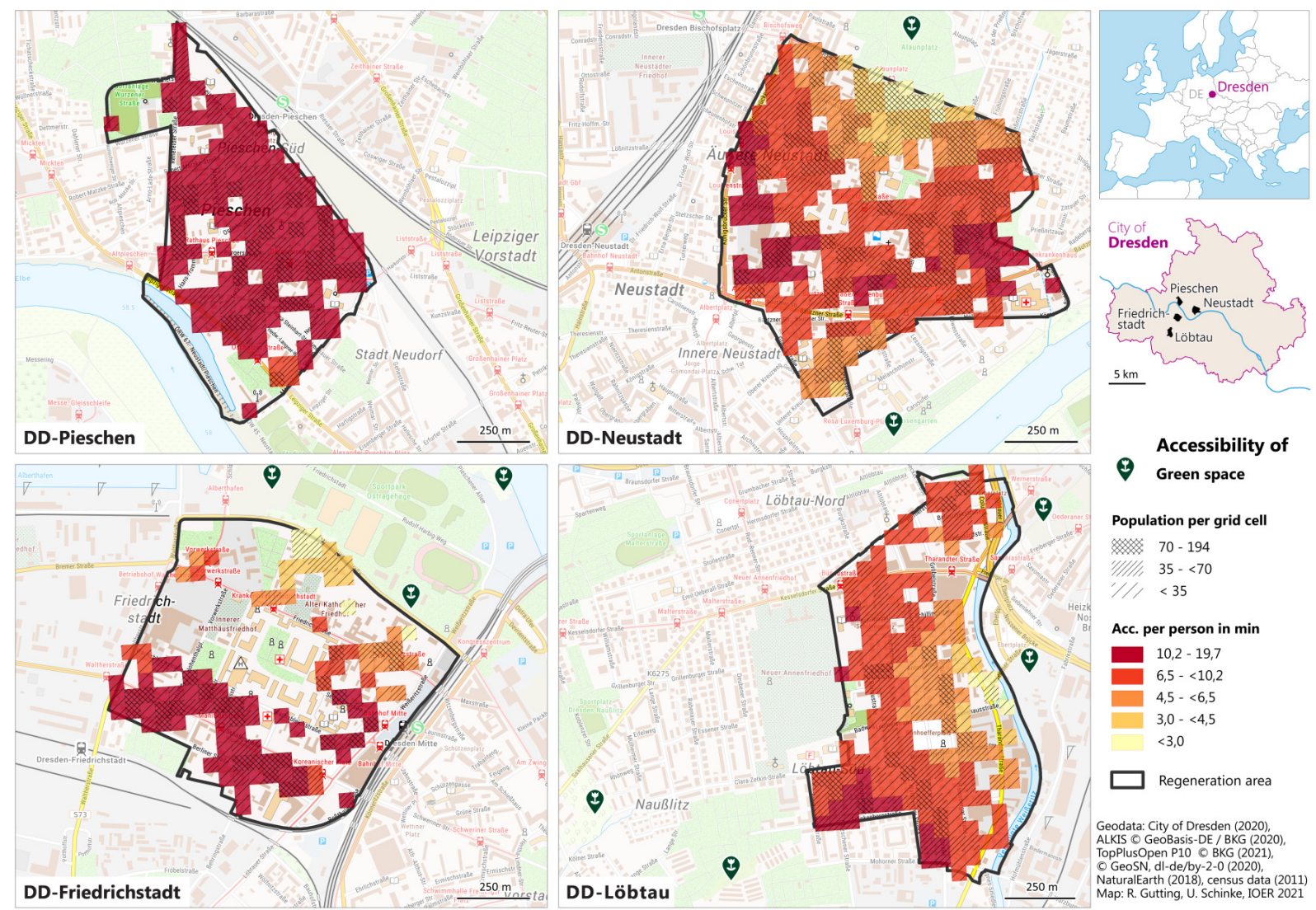

Figure 5. Grid cells showing population density and walking distance in minutes to nearest green space.
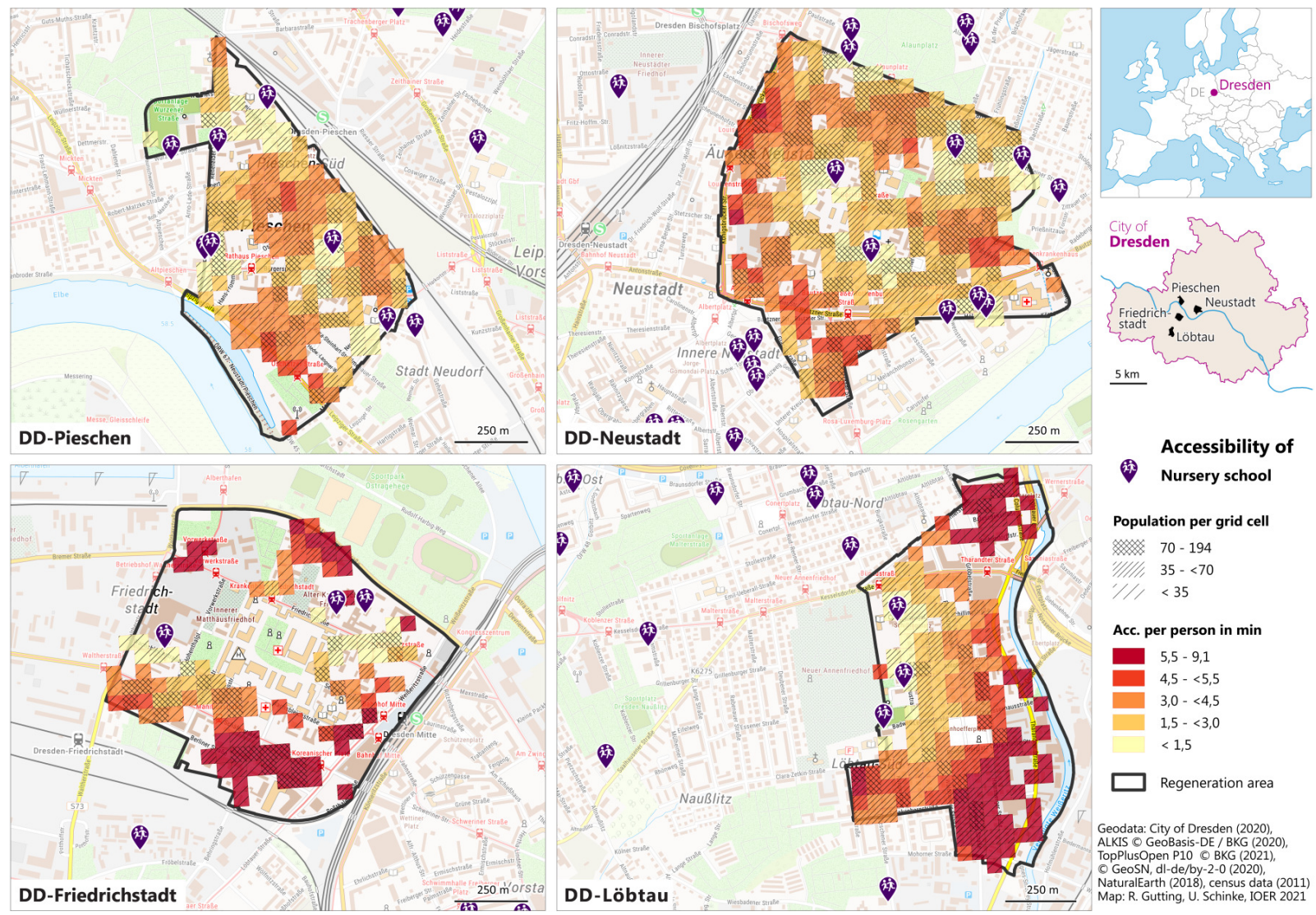

DD-Friedrichstadt

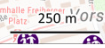

DD-Löbtau

Figure 6. Grid cells showing population density and walking distance in minutes to nearest nursery school. 
social amenities (Figures 3 to 6), representing the average number of minutes that each person within a $50-\mathrm{m}$ grid cell must walk to reach the nearest amenity. By superimposing these layers, it is possible to pinpoint areas within the regeneration areas which show poorer accessibility as well as high population densities. The population-weighted accessibility index is shown in Figure 7.

We also calculated the city-wide accessibility, i.e., average walking distance (in minutes) per person for each of the four amenities, to serve as a benchmark for the neighbourhood results below. In general, we can say that all four basic amenities can be reached in less than $11 \mathrm{~min}$ from each residential building. Due to the prevalence of facilities for daily need (supermarkets) and general practitioners, these are associated with rather short walking times averaging $6.6 \mathrm{~min}$ per person. Nursery schools can also be reached in only $5.5 \mathrm{~min}$. In comparison, an average walk of $10.2 \mathrm{~min}$ is required to reach the nearest park or forest.

At sub-neighbourhood level, our small-scale analysis enables a precise localisation of high population densities affected by poor accessibility (Figures 3 to 6). Grid cells with walking distances above city-wide average are marked in dark red. The socially disadvantaged neighbourhood of DD-Friedrichstadt, for example, shows areas with average walking distances of over $6.6 \mathrm{~min}$ - utes to facilities for daily need clustered in the north and east which comprise $38 \%$ of the neighbourhood population (Figure 3). High population densities of up to 190 people per grid cell and poorer accessibility can be found especially in the eastern parts of this regeneration area. Regarding access to general practitioners, areas with above-average walking distances of more than 6.6 minutes per person and high population densities (42\% of the neighbourhood population) are seen in the south and west (Figure 4). The proportion of such areas in the other three neighbourhoods is significantly lower. Due to the high density of facilities in DD-Neustadt, for example, there are no grid cells with walking distances above the city-wide average either for facilities of daily needs or general practitioners.

Our small-scale analysis also identified aboveaverage walking distances to green spaces (Figure 5). Here DD-Pieschen particularly stands out: Residents in almost all grid cells (covering $97 \%$ of the population) need more than $10.2 \mathrm{~min}$ to walk to the nearest park or forest. Large parts of the southern regeneration area of DD-Friedrichstadt also show above-average walking distances (70\% of inhabitants) associated with high population densities. In the other two neighbourhoods, DD-Neustadt and DD-Löbtau, only a small share of the population has to walk longer than $10.2 \mathrm{~min}$ to reach green spaces. Nevertheless, individual grid cells
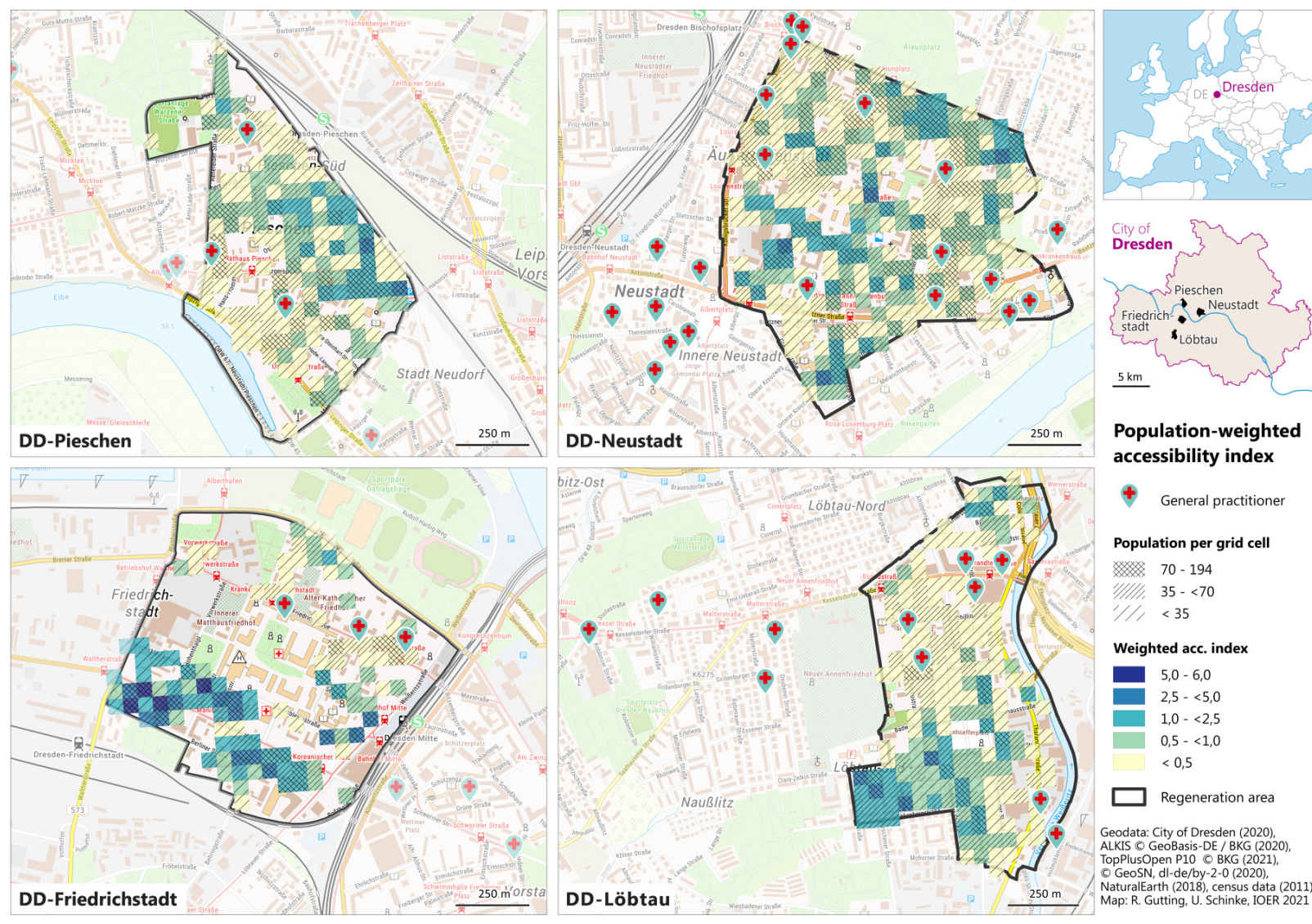

Population-weighted accessibility index

† General practitioner

Population per grid cell $70-194$ $70-194$
$35-<70$ $<35$

Weighted acc. index
$5,0-6,0$
$2,5-<5,0$
$1,0-<2,5$
$0,5-<1,0$
$<0,5$
$\square$ Regeneration area
Geodata: City of Dresden (2020),
ALKIS (GeoBasis-DE / BKG (2020),
ToplusOpen P10 0 BKG (2021),
OGeoSN, dl-de/by-2-0 (2020),
NaturalEarth (2018), census data (2011)
Map: R. Gutting, U. Schinke, IOER 2021

Figure 7. Grid cells showing population density and population-weighted accessibility index regarding access to general practitioners. 
with high population densities and poor accessibility can also be found in the west and east as well as in the south-west of these neighbourhoods. Regarding nursery schools (Figure 6), grid cells indicating longer distances than the city-wide average of $5.5 \mathrm{~min}$ per person can be identified in the northern and southern residential areas of DD-Friedrichstadt and DD-Löbtau. These comprise around $30 \%$ of the local populations with some high densities of up to 190 people per grid cell, especially in southern parts of DD-Friedrichstadt.

As described above, the two information layers can be linked for easier interpretation by means of the indicator "population-weighted accessibility index." Figure 7 shows the results for this indicator regarding access to general practitioners. Only in DD-Friedrichstadt do we see any grid cells with a value above five. In this case, the four cells encompass around 500 residents, who thus live in high-density locations with poorer accessibility due to longer walking distances. However, it should be noted that the highest value, namely six, is still considerably under the maximum value of 10 . No problematic areas can be identified in the other three neighbourhoods, where over $90 \%$ of the grid cells show values less than 2.5 .

\section{Discussion}

\subsection{Mapping Results}

The presented method is able to correctly estimate populations at the level of the city districts with an accuracy of up to around $90 \%$. In combination with network analysis tools and geo-referenced data, we determined spatial accessibility for four types of social amenities in urban regeneration areas within the city of Dresden, expressed as average walking distance (in minutes) or by means of a population-weighted accessibility index for a smallscale $50-\mathrm{m}$ grid. The applied methods and the exemplary results show that the presented technique allows status quo analysis, the monitoring of any changes, the assessment of comparable or different neighbourhood settings, or the comparative assessment related on a city-wide scale.

The practical value of any accessibility analysis is limited without a suitable benchmark. In our case, we took the overall city-wide average as our benchmark, measured in average minutes per person, and compared this with the value in each grid cell to determine the share of the population above or below this value. Comparisons with former points of time are also possible and are often used in planning practice for indicator-based monitoring (Stadt Dresden, 2017; Stadt Heidelberg, 2019). Legal requirements and guidelines may also specify benchmarks as distances measured in kilometres or in minutes (on foot or by car). Guidelines in Germany, Austria, or the Netherlands, for instance, state that $90-99 \%$ of local residents must be able to reach a general practitioner within 10 minutes by car (Klaus et al., 2020; Sundmacher et al., 2018). In Hamburg, Germany, nursery schools have to be reached within $20 \mathrm{~min}$ on foot or $10 \mathrm{~min}$ by car (Klaus et al., 2020). Applying these stipulations, we find that the neighbourhoods analysed here have a sufficient level of accessibility to general practitioners and nursery schools. In fact, the nearest facility can be reached in less than eleven minutes (general practitioner) resp. in about nine minutes (nursery schools) on foot. Only the accessibility of facilities for daily need is inadequate in parts of the neighbourhoods with more than 13 min' walk to the next facility compared to the minimum requirements of $10 \mathrm{~min}^{\prime}$ walk to the next shop specified in the literature (Kuhlicke et al., 2005). Such legal requirements or guidelines can certainly replace city-wide average values in small-scale analyses of accessibility.

For our population-weighted index, however, it was not possible to carry out a benchmark analysis due to the lack of a suitable comparative dataset. However, the index can be used to present an overall picture of the accessibility for a broader social topic. To do this, the index must be calculated for all important amenities within a specific social area. It is then possible to weight the individual indexes and combine them into an overall index. This is useful, for example, to show the overall accessibility of the health sector by combining the individual indexes for general practitioners, hospitals, and other specialist clinics into one index.

\subsection{Methodological Approach}

The population-weighted accessibility index is most useful when comparing smaller neighbourhoods that have similar structural characteristics. Analyses that incorporate both rural outskirts and urban centres should be avoided as the indicator values can then hide underlying disparities. For example, index values can be low in the centre and in the outskirts but for different reasons: (1) shorter distances and higher population densities in the centre; or (2) longer distances and lower population densities in the rural surroundings. Furthermore, the indicator is more suitable for identifying densely populated neighbourhoods with accessibility deficits because our methodology is designed to calculate higher values in such cases, trending towards the maximum value of 10 . It should also be noted that, for the purposes of balanced spatial planning, areas showing low population densities and accessibility deficits should still be given due consideration in upgrading programmes.

Another point to be considered is that spatial proximity is not the only factor governing people's use of social amenities. Insufficient capacity along with the reputation/quality of a nursery school or general practitioner, for example, can determine the level of use. The presented approach also ignores the specific needs of vulnerable groups such as refugees, the disabled or the socially disadvantaged. Regarding the disabled, for example, it would be necessary to set different parameters for the speed of travel between the home and the facilities 
in order to correctly calculate the average accessibility in minutes per person for a single residential building. The same applies to infrastructure related to various age classes. We also dealt with this question in our study by analysing the demand for nursery schools, which is a type of age-dependent infrastructure. In further studies, the demand for age-related accessibility could be determined for the residents of a residential building using demand-specific parameters for walking or driving speed.

\section{Conclusions}

The approach successfully shows how freely available (open source) geodata and official statistics can be used to estimate and map the population at the scale of residential buildings. In connection with spatial accessibility analysis, the presented approach can support municipal regeneration activities by: (1) showing the degree of accessibility of different types of facility in defined neighbourhoods; (2) comparing various neighbourhoods in relation to one another and to the whole city; and (3) monitoring the upgrading or degradation of areas. The notion of social sustainability as investigated by scholars can be methodologically substantiated to show spatial and thematic disparities in accessibility within small neighbourhoods and clearly illustrate these in maps. The overlaying of information on accessibility with population density within a grid cell can pinpoint residential buildings with poor access and thus help spatial planners design solution-oriented upgrading programmes that build on the achievements of previous measures towards sustainable urban regeneration.

Depending on data availability, our approach can be expanded to more social amenities. Accessibility to education and subsequently to job opportunities for example contributes to socially integrative urban regeneration in the same way as the analysed amenities and can be assessed with our approach. In addition, our workflow can be applied to other settings in urban regeneration areas worldwide. Open data on urban street networks is offered by OpenStreetMap or third-party providers such as DIVA GIS. The locations of social amenities are often already mapped as simple point geodata in publicly accessible online databases of the corresponding municipalities. By means of manual mapping, data gaps can be closed for some amenities such as supermarkets, parks, or schools. The small-scale mapping of the population, however, can prove challenging. Global databases are available that map population distributions at various resolutions (Global Human Settlement Layer, 2021; WorldPop, 2021). Our approach provides very small-scale results and is thus more useful for some applications than databases at lower resolutions. If basic data cannot be obtained, the individual calculation steps in the presented method can be simplified. For example, it is possible to make a reasonable assumption regarding the particular number of housing units per building level or to differentiate between the types of residential buildings on the basis of aerial photographs. By making use of freely available surface models (e.g., SRTM data), the number of building levels can be derived from an estimated height of individual levels. Further, if no data on household sizes is to hand, the number of people in a building can be estimated by assuming average household sizes depending on the building type.

\section{Acknowledgments}

This article has been elaborated within the project TRANS-URBAN-EU-CHINA ("Transition towards urban sustainability through socially integrative cities in the EU and in China"), funded by the EU's Horizon 2020 Research and Innovation Programme under Grant Agreement No. 770141. We thank our colleagues Ulrike Schinke for technical support and Robert Hecht for critical review. We also would like to thank Prof. Frank Schwarzbach for helpful input and support and the two reviewers for the critical review of our article, which helped us to improve it.

\section{Conflict of Interests}

The authors declare no conflict of interests.

\section{References}

Arellana, J., Alvarez, V., Oviedo, D., \& Guzman, L. A. (2021). Walk this way: Pedestrian accessibility and equity in Barranquilla and Soledad, Colombia. Research in Transportation Economics, 86, Article 101024. https://doi.org/10.1016/j.retrec.2020. 101024

Authoritative Real Estate Cadastre Information System. (2020). Liegenschaftskataster [Land survey register]. Staatsbetrieb Geobasisinformation und Vermessung Sachsen. https://www.geodaten.sachsen. de/liegenschaftskataster-3990.html

Biljecki, F., Arroyo Ohori, K., Ledoux, H., Peters, R., \& Stoter, J. (2016). Population estimation using a 3D city model: A multi-scale country-wide study in the Netherlands. PLOS ONE, 11(6), Article e0156808. https://doi.org/10.1371/journal.pone.0156808

Boisjoly, G., \& El-Geneidy, A. M. (2017). The insider: A planner's perspective on accessibility. Journal of Transport Geography, 64, 33-43. https://doi.org/ 10.1016/j.jtrangeo.2017.08.006

Bundesinstitut für Bau-, Stadt- und Raumforschung. (2021). Erreichbarkeitsmodell des BBSR [Accessibility model of the BBSR]. https://www.bbsr.bund.de/ BBSR/DE/forschung/raumbeobachtung/ Komponenten/Erreichbarkeitsmodell/ erreichbarkeitsmodell.html

Bundesinstitut für Bau-, Stadt- und Raumforschung, \& Federal Ministry for the Environment, Nature Conservation, Building and Nuclear Safety. (2016). Gemein- 
same Evaluierung der Programme-Stadtumbau Ost und Stadtumbau West [Joint evaluation of the programs-Urban redevelopment east and urban redevelopment west].

Bundesministerium des Innern, für Bau und Heimat. (2020). Holistic, sustainable, collaborative -50 years of the Urban Development Support Programme in Germany.

Büttner, B., Kinigadner, J., Ji, C., Wright, B., \& Wulfhorst, G. (2018). The TUM Accessibility Atlas: Visualizing spatial and socioeconomic disparities in accessibility to support regional land-use and transport planning. Networks and Spatial Economics, 18(2), 385-414. https://doi.org/10.1007/s11067-017-9378-6

Colantonio, A., \& Dixon, T. (2009). Measuring socially sustainable urban regeneration in Europe. Oxford Institute for Sustainable Development.

del Aguila, M., Ghavampour, E., \& Vale, B. (2019). Theory of place in public space. Urban Planning, 4(2), 249-259. http://dx.doi.org/10.17645/up.v4i2.1978

Doğan, U., Koçak Güngör, M., Bostancı, B., \& Yılmaz Bakır, N. (2020). GIS based urban renewal area awareness and expectation analysis using fuzzy modeling. Sustainable Cities and Society, 54, Article 101945. https://doi.org/10.1016/j.scs.2019.101945

European Commission. (2021). Guidance and methodological resources. https://ec.europa.eu/regional_ policy/en/policy/evaluations/guidance

Gargiulo, C., Zucaro, F., \& Gaglione, F. (2018). A set of variables for the elderly accessibility in urban areas. TeMA-Journal of Land Use, Mobility and Environment, 2018(Special Issue 2), 53-66. https://doi.org/ 10.6092/1970-9870/5738

Geurs, K. T., \& van Wee, B. (2004). Accessibility evaluation of land-use and transport strategies: Review and research directions. Journal of Transport Geography, 12(2), 127-140. https://doi.org/10.1016/j.jtrangeo. 2003.10.005

Gharebaghi, A., Mostafavi, M.-A., Chavoshi, S. H., Edwards, G., \& Fougeyrollas, P. (2018). The role of urban and social factors in the accessibility of urban areas for people with motor and visual disabilities. International Journal of Geo-Information, 7(4), Article 131. https://doi.org/10.3390/ijgi7040131

Global Human Settlement Layer. (2021). Concepts and methodologies of the data produced by the GHSL. https://ghsl.jrc.ec.europa.eu/data.php

Handy, S. L., \& Clifton, K. J. (2001). Evaluating neighborhood accessibility: Possibilities and practicalities. Journal of Transportation and Statistics, 4(2), 67-78.

Hecht, R., Herold, H., Behnisch, M., \& Jehling, M. (2019). Mapping long-term dynamics of population and dwellings based on a multi-temporal analysis of urban morphologies. International Journal of GeoInformation, 8(1), Article 2. https://doi.org/10.3390/ ijgi8010002

Huang, L., Zheng, W., Hong, J., Liu, Y., \& Liu, G. (2020). Paths and strategies for sustainable urban renewal at the neighbourhood level: A framework for decisionmaking. Sustainable Cities and Society, 55, Article 102074. https://doi.org/10.1016/j.scs.2020.102074

Hull, A., Silva, C., \& Bertolini, L. (Eds.). (2012). Accessibility instruments in planning practice. COST European Science Foundation. http://www.accessibility planning.eu/wp-content/uploads/2012/06/Report1-FINAL-as-for-30062012-V2.pdf

Ignaccolo, M., Inturri, G., Giuffrida, N., Pira, M. L., Torrisi, V., \& Calabrò, G. (2020). A step towards walkable environments: Spatial analysis of pedestrian compatibility in an urban context. European Transport/Trasporti Europei, 76(6), 1-12.

Jensen, E. H., \& Munk, A. (2007). Kvarterløft. 10 years of urban regeneration. The Ministry of Refugees, Immigration and Integration Affairs.

Khan Academy. (2021). Identifying outliers with the 1.5xIQR rule. https://www.khanacademy.org/math/ statistics-probability/summarizing-quantitativedata/box-whisker-plots/a/identifying-outliers-iqrrule

Klaus, M., Käker, R., Mäs, S., \& Weitkamp, A. (2020). Daseinsvorsorge sichern und überwachen: Der Daseinsvorsorge-Atlas Niedersachsen [Securing and monitoring basic services: The Lower Saxony Basic Service Atlas]. Flächenmanagement und Bodenordnung, 82(5), 223-234.

Kolcsár, R. A., \& Szilassi, P. (2017). Assessing accessibility of urban green spaces based on isochrone maps and street resolution population data through the example of Zalaegerszeg, Hungary. Carpathian Journal of Earth and Environmental Sciences, 13(1), 31-36. https://doi.org/10.26471/cjees/2018/013/003

Korkmaz, C., \& Balaban, O. (2020). Sustainability of urban regeneration in Turkey: Assessing the performance of the North Ankara Urban Regeneration Project. Habitat International, 95, Article 102081. https://doi.org/ 10.1016/j.habitatint.2019.102081

Kuhlicke, C., Petschow, U., \& Zorn, H. (2005). Versorgung mit Waren des täglichen Bedarfs: Studie für die Verbraucherzentrale Bundesverband e.V [Supply of services for daily need: study for the Consumer Advice Center Federal Association]. Institut für ökologische Wirtschaftsforschung (IÖW) gGmbH.

Ma, X., Ma, C., Wu, C., Xi, Y., Yang, R., Peng, N., Zhang, C., \& Ren, F. (2021). Measuring human perceptions of streetscapes to better inform urban renewal: A perspective of scene semantic parsing. Cities, 110, Article 103086. https://doi.org/10.1016/ j.cities.2020.103086

Marshall, F. (2005). NDC national evaluation. Analysis of delivery plans 2004. Outcomes, floor targets and projects. Centre for Regional Economic and Social Research.

Meinel, G., Hecht, R., \& Herold, H. (2009). Analyzing building stock using topographic maps and GIS. Building Research \& Information, 37(5/6), 468-482. https://doi.org/10.1080/09613210903159833 
Metropolregion Hamburg. (2021). Erreichbarkeitsportal [Accessibility platform]. https://geoportal. metropolregion.hamburg.de/mrh_

erreichbarkeitsanalysen

Mohler, B. J., Thompson, W. B., Creem-Regehr, S. H., Pick, H. L., \& Warren, W. H. (2007). Visual flow influences gait transition speed and preferred walking speed. Experimental Brain Research, 181(2), 221-228. https://doi.org/10.1007/s00221-007-0917-0

Müller, B., Li, Q., Schiappacasse, P., Cai, J., \& Ma, E. (2019). Theoretical aspects of transition towards urban sustainability and the role of socially integrative cities (TRANS-URBAN-EU-CHINA Report D6.6). Leibniz Institute of Ecological Urban and Regional Development.

Nyseth, T., Ringholm, T., \& Agger, A. (2019). Innovative forms of citizen participation at the fringe of the formal planning system. Urban Planning, 4(1), 7-18. https://doi.org/10.17645/up.v4i1.1680

Pilot, M., Yigitcanlar, T., Sipe, N., \& Evans, R. (2006). Land use \& public transport accessibility index (LUPTAI) tool - The development and pilot application of LUPTAI for the Gold Coast. In C. Grainger (Ed.), Proceedings of the 29th Australian Transport Research Forum (pp. 1-18). Planning and Transport Research Centre (PATREC).

Rossetti, S., Tiboni, M., Vetturi, D., Zazzi, M., \& Caselli, A. (2020). Measuring pedestrian accessibility to public transport in urban areas: A GIS-based discretisation approach. European Transport/Trasporti Europei, 76(2). http://www.istiee.unict.it/sites/default/files/ files/1_2_ET_14.pdf

Rößler, S., Gutting, R., Schiappacasse, P., Süring, J., Müller, B., Weitkamp, A., Cai, J., Lin, J., Ma, E., Han, Y., \& Han, W. (2020). Land management instruments for socially integrative urban expansion and urban renewal in China and Europe (TRANS-URBANEU-CHINA Report D3.3). Leibniz Institute of Ecological Urban and Regional Development.

Saxon State Office for Geoinformation and Surveying. (2020a). Höhen- und Stadtmodelle [Terrain and surface models and 3D city model]. https://www. geodaten.sachsen.de/digitale-hoehenmodelle3994.html

Saxon State Office for Geoinformation and Surveying. (2020b). Hauskoordinaten [Building coordinates]. https://www.geodaten.sachsen.de/ liegenschaftskataster-3990.html

Saxon State Office for Geoinformation and Surveying. (2020c). Landschaftsmodelle [Landscape models]. https://www.geodaten.sachsen.de/ landschaftsmodelle-3991.html

Sheffield Hallam University. (2005). NDC national evaluation: Analysis of delivery plans 2004-Outcomes, floor targets and projects.

Shirazi, M. R., Keivani, R., Brownill, S., \& Watson, G. B. (2020). Promoting social sustainability of urban neighbourhoods: The case of Bethnal Green, Lon- don. International Journal of Urban and Regional Research. https://doi.org/10.1111/1468-2427. 12946

Silva, C., Pinto, N., \& Bertolini, L. (2019). Designing accessibility instruments: Lessons on their usability for integrated land use and transport planning practices. Routledge.

Smith, D. A. (2018). Employment accessibility in the London metropolitan region: Developing a multi-modal travel cost model using OpenTripPlanner and Average Road Speed Data (Working Paper No. 211). UCL.

Stadt Dresden. (2017). Zukunft Dresden 2025+ Integriertes Stadtentwicklungskonzept: Fortschreibung [Zukunft Dresden 2025+ Integrated urban development concept].

Stadt Dresden. (2020). Landeshauptstadt Dresden [Capital city of Dresden] [Data set]. https://opendata. dresden.de/DreiD

Stadt Dresden. (2021a). Sanierungsgebiet Löbtau [Regenaration area Löbtau]. https://www.dresden.de/ de/stadtraum/planen/stadtentwicklung/ stadterneuerung/sanierung/SanierungsgLoebtau.php

Stadt Dresden. (2021b). ESF-Gebiet DresdenFriedrichstadt [ESF area Dresden-Friedrichstadt]. https://www.dresden.de/de/stadtraum/planen/ stadtentwicklung/stadterneuerung/efre/esf-gebietdresden-friedrichstadt.php

Stadt Heidelberg. (2019). Heidelberger Nachhaltigkeitsbericht 2018: Indikatorengestützte Erfolgskontrolle des Stadtentwicklungsplans [Heidelberg sustainability report 2018: Indicator-based monitoring of the urban development plan].

Sundmacher, L., Schang, L., Schüttig, W., Flemming, R., Frank-Tewaag, J., Geiger, I., Franke, S., Weinhold, I., Wende, D., Kistemann, T., Höser, C., Kemen, J., Hoffmann, W., van den Berg, N., Kleinke, F., Becker, U., \& Brechtel, T. (2018). Gutachten zur Weiterentwicklung der Bedarfsplanung i.S.d. §§ 99 ff. SGB V zur Sicherung der vertragsärztlichen Versorgung [Expert opinion on the further development of basic service planning to ensure the supply of statutory health care]. Gemeinsamer Bundesausschuss.

Thüringer Ministerium für Infrastruktur und Landwirtschaft. (2020). Begleitforschung Stadtumbau Thüringen-Monitoringbericht 2019 [Accompanying research in urban redevelopment ThuringiaMonitoring report 2019].

Wassenberg, F., \& van Dijken, K. (2011). A practitioner's view on neighbourhood. Issues, approaches and experiences. Nicis Institute.

WorldPop. (2021). WorldPop methods. https://www. worldpop.org/methods

Zensus 2011. (2020). Gitterzellenbasierte Ergebnisse des Zensus 2011: Familien, Haushalte, Gebäude und Wohnungen [Grid-based results from the 2011 German census: Families, households, buildings and apartments]. https://www.zensus2011.de/DE/ 
Home/Aktuelles/DemografischeGrunddaten.html? $\mathrm{nn}=3065474$

Zheng, H. W., Shen, G. Q., \& Wang, H. (2014). A review of recent studies on sustainable urban renewal. Habitat International, 41, 272-279. https://doi.org/10.1016/ j.habitatint.2013.08.006
Zheng, H. W., Shen, G. Q., Song, Y., Sun, B., \& Hong, J. (2017). Neighborhood sustainability in urban renewal: An assessment framework. Environment and Planning B: Urban Analytics and City Science, 44(5), 903-924. https://doi.org/10.1177/ 0265813516655547

\section{About the Authors}

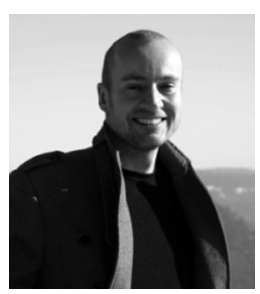

Robin Gutting (Dipl. Geographer) recently worked as a research associate at the Leibniz Institute of Ecological Urban and Regional Development (IOER, Dresden/Germany) and is now doing a Master's in Urban and Regional Science at Stellenbosch University, South Africa. As a consultant, his research interests are aimed at the development of models for small-scale forecasting of housing demand of certain household types. See also: https://www.prognose-und-planung.de/wer-wir-sind.html

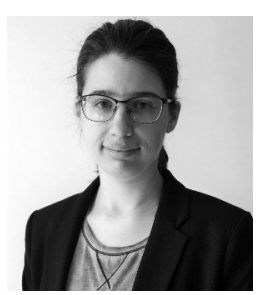

Maria Gerhold (B.Sc. Cartography/Geoinformatics) is a Master's student of geoinformatics at the University of Applied Sciences Dresden, Germany. She received her Bachelor's degree in cartography/geoinformatics in 2019. Her research interest is focussed on GIS technologies for analyzing, transforming, combining, and updating large-scale geodata using automated workflows.

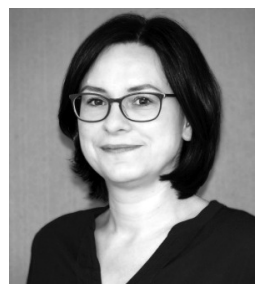

Stefanie Rößler (Dr.-Ing.) is a senior researcher at the Leibniz Institute of Ecological Urban and Regional Development (IOER, Dresden/Germany). She holds a diploma in landscape architecture and got her doctorate at Technische Universität Dresden in 2009. Her research interests are in urban sustainability transformation, urban regeneration, ecological aspects of urban development, and urban green space development. She particularly focuses on the role of formal and informal instruments of urban planning. 